\title{
浅谈土木工程施工现场质量管理过程中存在的问题及优化 对策
}

谢华君

广西建工集团联合建设有限公司

DOI:10.18686/bd.v2i8.1551

[摘 要] 在土木工程施工过程中,加强对现场施工的管理可以有效的提升现场施工项目的质量,降低施工中事故发生的概 率。另外通过现场管理制度以及方案的制定, 还可以对施工中存在的问题进行有效的预防和治理,进而提高综合质量分析, 保 证工程建设的安全。

[关键词] 土木工程;现场施工;治理

随着人们对土木工程施工质量要求的逐渐提高, 我国 及其建筑企业加强了对土木工程现场施工质量管理的力 度,同时不断的优化和改革管理模式,完善管理部门以及制 度的建立, 以此保证工程建设的安全进行。

\section{1 土木工程施工现场质量及管理的内容}

1.1 施工质量

在土木工程现场施工时, 为了保证施工质量的标准性, 先要明确施工的目标,之后要对施工的工期、成本、计划等 内容进行充分的了解和掌握, 同时还要对施工中各部门的 组织构建、施工流程以及管控措施等实行合理的规划,从而 保证土木工程施工的顺利完成。另外,在具体的施工作业前, 工作人员还应审核工程设计的具体内容, 保证施工操作符 合标准规范。

1.2 质量管理

土木工程现场施工质量管理工作的开展，一是要对质 量管理的标准、以及运行方式进行明确的掌控;二是要对质 量管理的方针、政策、目标以及职责进行充分的了解,从而 制定合理的质量管理体系和制度, 建立明确的管理流程,并 落实实施,并提前的预测和控制管理中存在的问题,进而提 升质量管理工作的水平。

\section{2 影响土木工程现场施工质量管理的因素}

土木工程施工的规模相对较大, 且其中涉及的内容也 较多,如果不能对各个环节展开合理管控,则会为下一环节 的施工埋下一定的安全隐患, 进而影响整个工程建设的质 量。从目前的土木工程施工来看,影响现场施工质量管理的 因素主要可以概括为以下几方面。

\section{1 安全管理问题}

土木工程现场安全管理主要有:(1) 对现场员工操作的 行为、安全管理的内容以及技术风进行相应的管理和控制 工作。(2)合理的管控施工设备的情节、运行以及维护。(3)严 格的控制施工现场的人员以及安全措施。其主要体现在,现 场施工人员安全设施的佩戴、高空作业人员防护措施的的 标准性等进行严格的管理和控制。另外还要对施工人员的
专业水平以及设备操作的规范性予以监督和控制, 从而有 效的降低现场安全事故发生的几率。但是, 在目前的土木工 程施工作业中,人们对于安全管理的认知能力不足, 相应安 全设施配置不完善, 这都会导致工作人员现场安全设施的 佩戴和使用频率较低, 使得现场施工中安全事故发生的概 率不降反涨, 这对工程建设质量构成了严重的威胁。

2.2 施工质量达不到标准要求

土木工程施工质量对于建筑的整体质量、后期的使用 以及观赏效果都有着严重的影响。但是现阶段土木工程的 工作人员,对于该情况的意识存在偏差,一味的追赶工期,这 就给人们的生命以及财产安全带来了极大的威胁。比如说 在钢筋绑扎作业时, 施工人员未按照具体的技术要求实行 操作, 这样不仅会使钢筋露出刮伤工作人员, 还会影响工程 的美观性。

2.3 质量监管工作不合理

质量监管部门是土木工程现场施工质量管理中的重要 组成部分, 很多施工质量问题的出现都是由于监管部门没 有履行其职责,监管力度不严所造成的。比如说,在材料管理 时,为了追赶工期,很多材料还未通过审核就被应用到工程 施工中,监管部门自身职责无法履行,形同虚设。结合我国建 筑企业的具体情况分析, 监管部门职责无法履行的主要原 因为: (1)管理人员缺乏质量管理监督意识,导致监管部门无 法发挥自身的职责; (2)一些企业并未进行监管部门的构件, 导致质量管理监督工作无人执行,使得管理工作较为混乱; (3)部分企业为了降低施工成本, 会存在随意更改图纸的情 况, 且这些企业的监管人员也都是由其他部门人员兼职代 理的,最终造成工程项目验收不过关,加大了企业损失。

2.4 施工材料的质量问题

材料是工程建设的基础, 其质量的好坏与建筑物的质 量是紧密联系在一起的。不过由于施工部门体系构建不完 全,在施工过程中,肆意的降低材料成本,引进很多价格较低, 质量较差的施工材料应用到工程建设中, 或者通过一些不 正规渠道进行材料的采购, 进而导致土木工程施工质量存 
在问题,甚至危及人们的生命安全。另外由于材料质量不合 格,势必会影响其性能的发挥,进而降低建筑结构的功能,使 其在灾害发生时,失去了原有的抵抗能力。

2.5 施工工方案制定和设施问题

施工方案的制定和实施是确保土木工程顺利进行的主 要依据。施工方案设计的合理性,需要结合现场施工的具体 情况以及影响因素进行综合的考量。但是目前很多设计人 员在方案设计和制定过程中, 并不能有效的整合工程的资 源信息,这就会降低方案设计的科学性、可行性,导致工程建 设质量存在诸多问题。再加上专业人员稀缺, 且工作人员的 能力较差, 这也对施工质量的提高带来了阻碍。

\section{3 土木工程现场施工质量管理的优化措施}

为了帮助企业建立良好的信誉和口碑, 促进企业长远 目标的实现, 施工部门需要不断的加强现场施工质量管理 的质量和效果, 只有这样才能有效的提升企业的竞争优势, 使其在社会发展中占有重要的一席之地。通过对现场施工 质量管理中的问题分析, 找出加强现场施工管理质量的相 应措施,其内容有以下几方面。

3.1 加强土木工程现场施工环节的监督力度

首先,在管理工作开展过程中,企业应建立一些经验丰 富、专业能力强的施工监管队伍,并明确其监管职责,确保施 工各环节操作的标准性; 其次,制定科学合理的管理制度,通 过分层管理的模式来保证施工质量。同时还要根据工程建 设的特征, 有针对性的开展质量管理工作, 以保证整体施工 质量的标准性; 再次,加强监理部门的职责,并将其应用到具 体的施工中来。监理部门是施工质量控制的主要管理者,在 实际的工作中, 监理人员不仅要明确各项目的建设情况, 还 要对施工质量进行合理的检测和控制, 一旦发现不合理情 况的出现, 监理人员有责任要求施工人员返工操作, 直到质 量与实际的建筑要求相符方可开始后期的施工操作。最后, 对施工现场人员的素质进行检测, 并抽查施工人员的职业 技能, 这样才能更好的督促施工单位定期对施工人员展开 技术培训。另外,企业在监理部门构建过程中,还应该选择一 些有经验的专业人士, 并定期对监理人员进行专业知识和 技能的培训,建立建立责任制,做到责任到人,责任到岗,严禁 出现玩忽职守、滥用职权的现象,通过严格的管理,提高建筑 施工单位的施工质量。

3.2 强化施工现场管理的质量和效果

现场施工管理的有序进行对于保证施工的安全性,降 低管理的混乱性有着重要的意义。为此管理人员应加强对 现场管理的重视度,建立完善的管理体系,明确管理秩序、施
工工艺的操作流程以及质量管理的相应内容, 从而强化现 场施工管理的水平和效果。同时还要建立一套科学合理并 且行之有效的现场管理制度. 且管理人员要坚持责任到人 原则,严格进行管理。

与此同时,树立员工强烈的责任感,并对于员工要赏罚 分明,这样可以更加刺激员工的学习动力, 提高自己的专业 能力和综合素质,进而为增强施工效率, 保证施工质量奠定 基础。另外,在现场管理工作时,施工的每一个环节都必须严 格按照现场管理制度进行,对存在的违规情况,一经发现,则 视情节严重性对其实行合理的处罚。

\section{3 完善施工环境的构建}

充分的掌握现场施工环节对于施工作业的顺利开展, 要对施工中可能存在的突发情况有着良好的导向作用。比 如施工中噪音对周边居民生活的影响。这些注意事项在施 工人员的培训期间, 就应该对其重点教育, 培养施工人员建 立科学合理的施工理念,减少矛盾的发生。同时在方案设计 时, 设计者一定要考虑到气候和交通因素对施工条件造成 的影响,进而完善施工方案规划的准确性,提升其使用效率, 做好突发事件的防范措施,避免问题的产生。

3.4 发挥安全评价体系的作用,实现风险评估

为了对施工中存在的安全问题进行有效的控制和监 督,需要建立一套完善的安全评价体系。参照该体系可根据 施工过程中, 各个环节所包含的风险因素及对工程质量的 威胁程度展开分析, 进而将可能发生危险的系数降到最低.

\section{4 结语}

在土木工程施工中,为了保证现场施工的质量,避免问 题的发生,除了要制定严格的质量管理体制外, 还要对施工 中各种复杂的影响因素予以充分的分析和研究, 这样才能 提高图纸以及施工方案设计和规划的合理性、科学性,提升 方案的实施效率, 保证施工质量的标准。再者, 还要加强施工 各环节操作的监督和管控力度, 及时的解决施工中出现的 突发事件, 以此降低其对后续环节的影响, 确保土木工程现 场施工的安全。

\section{参考文献:}

[1]王星.土木工程施工现场质量管理过程中存在的若 干问题探讨[J].门窗,2018,(02):178.

[2]修大奎.新形势下的土木工程施工技术分析[J]. 黑 龙江科学,2018,9(09): 108-109.

[3]林建裕. 浅谈土木工程施工现场质量管理过程中存 在的若千问题[J].智能城市, 2018,4(02):74-75. 